\title{
Individual Access to Implementing Foreign Policy: A Perspective from Russian Constitutional Law
}

\author{
Gennady Chebotaryov, LL.D. \\ Tyumen State University, Department of Constitutional and Municipal Law, Professor \\ mariya.riekkinen@abo.fi

\section{Mariya Riekkinen, D.Sc.}

Tyumen State University, Russia, Department of Constitutional and Municipal Law, Professor, Åbo Akademi University, Finland, Department of Social Sciences, Business, and Economics, post-doctoral researcher mariya.riekkinen@abo.fi

Pekka Riekkinen, LL.Lic.

University of Turku, Finland, Department of Law, Researcher pekka.riekkinen@utu.fi

\section{Doi:10.5901/mjss.2015.v6n4s3p424}

\begin{abstract}
The role of civil society in implementing Russia's foreign agreements belongs to the most relevant themes of this article. Various avenues for such participation are studied on the basis of disparate provisions of Russian political documents, the decrees of the public authorities. According to the 2013 Concept of External Policy, Russia is increasingly relying on "soft power" in promoting its foreign political course, exemplified hereby by Nordic-Russian co-operation. Insofar as the mechanisms of "soft power" are entrenched in civil society, this article focuses on legal norms empowering NGOs, universities, and individuals to engage in implementing international agreements ( on the example of Nordic-Russian agreements). The author is preoccupied with several issues: How Russian legal thought conceptualizes Russia's "soft power" approach with respect to the Nordic states? What are the contents of this approach? What opportunities are provided for Russian NGOs, universities, and firms in order to engage in implementing "soft power" within the frames of Nordic-Russian agreements on co-operation? How (if at all) Russian law empowers civil society to collaborate with the state in implementing its "soft power" policies?
\end{abstract}

Keywords: Russian constitutional law, public participation, political rights, access to implementing foreign policy, Nordic-Russian co-operation

\section{Introduction}

Russia, which is mostly seen as a hard power state, expresses interest in pursuing the "soft power" approach as, following Congyan Cai, "a lack of soft power may weaken the exercise of a country's hard power or make its exercise less self-regulated" (Congyan, C., 2013). This article examines how Russian citizens, their associations and NGOs can participate in implementing Russia's "soft power" approach towards the Nordic states in absence of procedural norms empowering civil society to engage in implementation of foreign policy. From the perspective of law, our discussion aims to define legal avenues for public participation in implementing foreign policy of the Russian Federation.

"Soft power" - a concept, elaborated by J. Nye, a scholar from Harvard University - signifies policies implemented by virtue of appealing to other parties in order to make them understand own political goals (Nye, J. \& Donahue, J., 2000). According to Nye, as a result of the ability to persuade other states or parties, the probability of a state to achieve the desired political objectives increases (Watanabe, Y., McConnell, D. \& Nye, J.S., 2008, ix). The "soft power" of a state has three main sources: its culture; its political values; its foreign policies (Nye, J.S., 2004, 11). In the most general terms, "soft power" utilizes other means than military power in order to promote the foreign policy aims of a state. It can be implemented by virtue of an array of tools, e.g. promoting one's own cultural values in order to gain a positive image of a state, enhancing the educational potential of the universities in order to influence intellectual development at the international level, using economic resources not as a source of coercion, but as an attraction for foreign investors, conducting public diplomacy in such a way that would earn sympathy for political leaders from a foreign audience, using 
the instruments of freedom of speech and the mass media to disseminate a positive image of the political and legal system of a state, etc. According to J. Nye, the "soft power" of a state "rests primarily on three resources: its culture (in places where it is attractive to others), its political values (when it lives up to them at home and abroad), and its foreign policies (when they are seen as legitimate and having moral authority)." (Nye, J.S., 2004, x).

We examine legal regulation enabling public participation in implementing Russia's "soft power" approach, as applied to Russia's co-operation with the Nordic states. Although we do not attempt to assess the impact of Russia's "soft power" approach. We distil the procedures for public participation in promoting what Russia understands as "the softpower approach" from the international treaties. The Nordic states and Russia have concluded many bi- and multilateral agreements on co-operation in such areas as: the heritage of the Baltic Sea region, which is not only a cultural heritage but also a cemetery for nuclear and other dangerous weapons, left after the Second World War; the developments in the Barents Euro-Arctic region, which entail environmental issues as well as proprietorship over natural resources; strengthening trade, research, and educational partnerships; maintaining dialogues on pricing for energy supplies. (Among such agreements are: a. bi- and multilateral agreements concluded at the governmental level: i.e. the Agreement between Norway and Russia On Cross-Border Co-operation; Agreement between Russia and Norway On Co-Operation in the Field of Environmental Protection (framework agreement) of 3 September 1992; Agreement between the Government of Russia and Denmark On Cooperation in the Field of Environmental Protection (framework agreement) of 5 January 1993; Agreement between the Government of the Russian Federation and the Kingdom Sweden Government about cooperation in the field of environmental protection (framework agreement) of 3 February 1993; The Treaty between Russia and Norway On Maritime Delimitation and Cooperation in the Barents Sea and the Arctic Ocean of 15 September 2010; Agreement between the Government of Canada, the Government of Denmark, the Government of Finland, the Government of Iceland, the Government of Norway, the Government of Russia, the Government of Sweden, and the Government of the United States of America On Cooperation in Aeronautical and Maritime Search and Rescue in the Arctic of 12 May 2011; Agreement between the Government of Russia and the Government of Finland On CoOperation in Murmansk Oblast, Karelian Republic, Saint-Petersburg, and Leningrad Oblast; Agreement between the Government of Sweden and the Government of Russia On the Swedish Culture and Information Centre in SaintPetersburg and the Terms of its Activities; the Convention on the Protection of the Marine Environment of the Baltic Sea Area, 1992, Treaty between Denmark, Estonia, Finland, Germany, Latvia, Poland, Russia, and Sweden On the Privileges and Immunities of the Baltic Marine Environment Protection Commission, 2 February 1998; Agreement between the Government of Russia and the Government of Iceland On Co-operation in the Sphere of Fishery of 3 April 2000; Agreement between the Russia, Iceland and Norway Concerning Certain Aspects of Cooperation in the Area of Fisheries of 15 May 1999. b. Agreements on co-operation concluded at the regional government level: i.e. the agreement between the Government of Nizhegorod Oblast and the Administration of the Pirkanmaa Communities of Finland on trade, economic, science, technical, and cultural cooperation, 2009; c. Agreement on co-operation, concluded at the level of universities and firms, i.e. many agreements on cooperation, concluded between Russian and Nordic universities; agreements between corporations regarding the construction of the Nord Stream Pipe-Line. $d$. Declarations are also considered: Declaration on Arctic Co-operation between Russia and Iceland of 29 November 2011; Declaration on Partnership for Modernization between Russia and Iceland of 12 September 2011; Declaration On the Fundamentals of Relationships between Russia and Iceland of 19 December 1994). Both the Nordic states and Russia are state parties to the treaties concerned, however most examples of these treaties are not specifically targeted at "Nordic-Russian" cooperation. This is due to the fact that definition of "Nordic-Russian co-operation" is an ambiguous task per se. Moreover, most of this article refers to co-operation on the level of states.

Our emphasis is on legal mechanisms, which allow civil society to participate in implementing Nordic-Russian agreements. According to J. Nye, "the instruments of soft power are not fully under the control of governments. While governments control policy, culture and values are embedded in civil societies" (Watanabe, Y., McConnell, D. \& Nye, J.S., 2008, 13). However, the state can not prescribe rules to civil society on "soft power" practices, yet it is dependent on civil society in implementing "soft power" policies. Hence, it is important for Russian statutory law to provide opportunities for accommodating transparent participatory practices, stimulating civil society to act in conjunction with the state in implementing "soft power" approach. Our main goal is to find legal mechanisms enabling Russian NGOs, firms, and universities to engage in implementing the "soft power" approach to Nordic-Russian co-operation within the framework of international agreements.

This article consists of several sections. A brief discussion arguing for the Russia's potential to implement "soft power" policies towards the Nordic states is provided for the reader after the introduction to the topic. Having considered these issues, the author will examine in which modes the Russian NGOs, universities, and firms can engage in implementing Russia's "soft power" approach towards the Nordic states. The modes of public participation are considered 
in this article as concrete procedures enabling such participation, delineating the organizations, involved in this process, as well as the substantive activities for co-operation within the frames of agreements on co-operation.

The author will analyze legal framework, enabling Russian NGOs, firms, and universities to participate in implementing Russia's "soft power" policy towards the Nordic states when co-operating with their partners within the frames of international agreements. The modes of implementing the "soft power" approach of the Russian Federation towards the Nordic states are examined on the basis of collecting and analysing fragmented information about the contents of Russia's "soft power" from many statutory provisions as well as in many political documents.

\section{2. "Soft Power" Approach Towards the Nordic States: Should Russia Bother?}

In accordance with the 2013 Concept of External Policy, Russia is looking for "step-by-step practical co-operation" with the Nordic states (par. 65). Mutual interest in Nordic-Russian collaboration can be explained by the unique geo-political situation of all of these regions, as well as strategic military and security interests, the importance of sea trade, fishery, and many other factors. The Ukrainian crisis, however, contributed in growing isolation of Russia in terms of co-operation with foreign states. In particular, G-8 leaders to whom Russia joined in 1998 issued the so-called Hague Declaration of 24 March 2014, indicating that they would not attend a planned G-8 Summit in Sochi in June 2014 but would continue without Russia in G-7 format (European Commission, Statement, The Hague Declaration following the G7 meeting on 24 March, The Hague, 24 March 2014, available at: http://europa.eu/rapid/press-release_STATEMENT-14-82_en.htm.). In accordance with par. 3 of this Declaration, this decision was made "in response to Russia's violation of Ukraine's sovereignty and territorial integrity, and to demonstrate ... determination to respond to these illegal actions." Although the G-8/G-7 platform does not regard Nordic-Russian co-operation, this example, nonetheless, demonstrates Russia's weakening position in international affairs. Nevertheless, according to its official Concept of Foreign Policy, Russia relies on the pursuits of "soft power", maintaining international dialogues with foreign states. Provisions regarding the use of "soft power" in Russian foreign policy, including a regional policy with the Nordic states, are nowadays officially acknowledged in Russian political policy papers.

When it comes to Nordic-Russian co-operation, Russia still participates in the following institutionalized partnership mechanisms relevant to implementing the agreements on co-operation in the spheres of culture, trade, environmental protection, and education: the Arctic Council, the Northern Dimension, the Council of the Baltic Sea States (CBSS), and the Barents Euro-Arctic Council (BEAC)/Barents Regional Council (BRC). The Russian Association of Indigenous Peoples of the North (RAIPON) is a permanent representative in the Arctic Council. To remind, RAIPON is also represented in the Public Chamber of the Russian Federation. This association can act as a mediator with other institutions of civil society in Russia. Formally established in 1996 by the Ottawa Declaration (Declaration on the Establishment of the Arctic Council, Adopted in Ottawa on 19 September 1996, available at: www.arctic-council.org), the Arctic Council is "a high level intergovernmental forum to provide a means for promoting cooperation, coordination and interaction among the Arctic States" (The official web-page of the Arctic Council is available at: http://www.arcticcouncil.org/index.php/en). According to this Declaration, the Council relies on the involvement of the Arctic indigenous communities and other Arctic population in its activities (par 1 (a)). Russia can implement its "soft power" towards the Nordic states acting via the RAIPON representatives in the Arctic Council. Both, Russia and all the Nordic states, except Denmark, are represented in this Council.

Notwithstanding the overall condemnation of the referendum held in Crimea coupled with Russia's overall policy towards the Ukraine, Russia continues its pursuits to rehabilitate its soft-power approach. As for the definition of what is Russia's "soft-power" approach towards the Nordic states, we keep up with the understanding of "soft-power" reflected in the official Russian documents, analysed below. The exact contents and definition of "soft power" have not as yet been officially defined in Russia. Overall, according to the political documents and official statements, studied in this article, the Russian leaders understand as "soft power" an array of alternative methods of diplomacy varying from public diplomacy to international co-operation and dialogues which is vague and perhaps not easy to delineate from propaganda or public diplomacy. For the purposes of this article, Russia's "soft power" approach is understood as promoting Russia's cultural impact, sustainability of Russia's political and economic system; technological and scientific developments in order to maintain an image of a benevolent state and in order to have positive impact on citizens of foreign states.

True, the Russian Federation has never denied that it puts a lot of emphasis on its military forces, for the first time in the recent history of this state, the central political document, i.e. the 2013 Concept of External Policy, emphasizes that politico-military conglomerations "cannot resist the whole spectrum of trans-border threats and challenges" (par. 9). Nonetheless, such statements from Russia, the international image of which in the eyes of the Nordic audience is ambiguous, might sound like an overstatement. When it comes to "soft power", Russia exercises little influence in 
international affairs. Unlike Finland, Sweden, Norway, and Denmark, Russia was not mentioned in the top-20 ranked nations according to their "soft power" policies by the 2012 survey, organized by Monocle - a global affairs magazine founded by T. Brûlé (Who Rules the World? - Monocle's Top Twenty (Overview), available at: http://howtoattractpublic sandinfluencestates.wordpress.com/2012/11/20/who-rules-the-world-monocles-top-twenty-overview/).

The Nordic states share a lot in common, when it comes to language and culture which are cardinally different from the language and culture of Russia. B. Barber, an author of a theory of "Strong Democracy," and many other academicians remarked that shared language and free communication make politics "intelligible" (Barber, B.R., 1990, 197). Hence, language barrier can explain a lack of free communication when the Nordic states learn about Russia, its social, political, and legal system, mainly from the mass media.

Sakwa claims that intrinsic to Russian character, society, and political power, such ambiguities are reflected at the structural level (Sakwa, R., 2012, 465), which can explain the independent political course, which Russia has pursued throughout her history. This may explain why for many academicians, including Russian scholars, Russia's policy, both foreign and domestic, is anything but predictable (Ticktin, H., 2008). For example, political fluctuations in Russia, regarding the direct election of the Russian Governors - rejected in 2004 and re-introduced in 2012 - are confusing.

Although Russian political doctrine de jure proclaims that Russian foreign policy is based inter alia on the principles of predictability and transparency, for many foreigners Kremlin decision-making remains, following Hill, who has discussed Russian "soft power" policy, "a black box" (Hill, F., 2006, 345). Scholars, examining Nordic-Russian relationships are sometimes critical regarding Russia's implementation of foreign policy. Concerns are expressed, regarding the security of energy supplies from Russia(Grant, T., 2009) and Russia's policy of determining energy prices (Hobér, K., 2009). Extensive Soviet/Russian intelligence activities with respect to the Nordic states are, perhaps, among the most widely shared allegations in scholarly literature. For example, intelligence-based explanations for the running aground of "the luckless Soviet submarine" (Ausland, J.C., 1986, 9) S-363 near the Swedish naval base in the early 1980s have already become well-known in the academic literature on Nordic security. The recent economic initiatives, related to the Nord Stream pipeline, also provide opportunities for Russia to practice surveillance behind the façade of supervising the energy infrastructure (Lucas, E., 2008). Public officials as well as political analysts, share their concerns in the mass media regarding the air exercises of Russia's strategic air force in close proximity to their borders (See, for example, the most recent statements from the officials of Sweden of 24.4.2013: http://www.svd.se/nyheter/inrikes/rysktflyg-ovade-anfall-mot-sverige_8108894.svd), to which the Russian response is that the flights near the border belong to the normal procedure of policing Russia's borders in the remote areas (Putin's statement: http://www.pravda.ru/ world/formerussr/17-08-2007/235574-avia-0/). Taking into account that the Russian Federation shares a border with 16 different states, which is a record number of borders in comparison to any other country in the World, such measures do not seem extraordinary. All these issues are further situated in academic literature within a broader perspective of Russian-EU relationships, in the context of Russia's potential to develop a viable modus vivendi with an expanded Europe (Legvold, R., 2007, 407). There are relatively few studies of how the concept of "soft power" is entrenched in legal order of the modern Russian Federation in order to harmonize its relationships with the Nordic states. Nevertheless, quite recently, Norwegian and Russian scholars have launched a project at Tromsø University, entitled "Neighbourly Asymmetry: Norway and Russia 1814-2014". Although this project focuses on Norwegian-Russian relations, it confines itself only to the Norwegian-Russian relationship and with special attention to history.

Hence, the authors remain aware of the criticism of Russia's potential to implement "soft power" approach in its international relationships. On the other hand, no strong arguments can be used to challenge the applicability of the "soft power" approach to Nordic-Russian co-operation. Modern studies in the area of Russia's "soft power" approach demonstrate that Russia has successfully implemented "soft power" policies towards the post-Soviet states due to the fact that the Russian economy is attractive to Central Asia and Russia is attempting to disseminate the Russian language and education by maintaining a system of Slavonic universities in Central Asia (Tsygankov, A., 2006). The said does not, however, exclude the possible existence of opinions, according to which Russia's "soft power" towards the ex-Soviet republics could be nothing else than an attraction of the Russian market for low-paid migrants. Obviously, the Russian strategy of "soft power" towards the Nordic states should be different. Let us try to systematize this strategy on the basis of available legal documents and their implementation.

\section{3. "Soft Power" in the Russian Legal System}

The term "soft power" was first introduced into the Russian official documents in 2010 by the programme document of the Russian Foreign Ministry "On the Main Directions of Russia's Foreign Political Course in the Area of Cultural and Humanitarian Co-Operation" (Osnovnye napravleniya politiki Rossiiskoi Federatsii v sfere mezhdunarodnogo kul'turno- 
gumanitarnogo sotrudnihestva", approved by the Ministry of Foreign Affairs of the Russian Federation on 18 December 2010, reproduced in the Russian law database "Consultant," available at: www.consultant.ru). This document mentioned that the "soft power" approach can contribute in strengthening the international authority of Russia, serving as "a valid proof testifying to the revival of the Russian Federation as a free and democratic state". The significance of the "soft power" approach for Russia was emphasized by the Foreign Minister Lavrov, who raised the issue of "soft power" during the first ever 2011 joint session of the RF Foreign Ministry and the Public Chamber of the Russian Federation. This event also conveyed a symbolic meaning. Insofar as "soft power" appeals not to governments but to individuals, by calling a joint session of the Foreign Ministry and the Chamber, which is the All-Russia advisory organ comprised of citizens (Public Chamber is a consultative organ, consisting of individuals and representative of various NGOs. RF, Federal'nyj zakon of 4 April 2005 No. 32-FZ "Ob Obshchestvennoj Palate Rossijskoj Federatsii" (with subsequent amendments, the most recent amendment of 23 July 2013), SZ RF, 11 April 2005, No. 15 item 1277, art. 20), the Russian Government is demonstrating that it co-operates with civil society when implementing external policy.

In 2012 the significance of Russia's reliance on "soft power" was reappraised by Vladimir Putin in his article, entitled "Russia and the Changing World" (Putin, V. (2012). Rossiya i menyayushchijsya mir. Moskovskie novosti, 27 February 2012). In this essay Putin welcomed the efforts of the NGOs and the universities in promoting the "soft power" approach, which he labeled as a mode of "civilized lobbying". Putin remarked that such civil society organizations as the "Russkij mir" (the Russian world) foundation or leading Russian universities enhance their partner network by finding new partners abroad and, thus, implement "soft power" policies. In December 2012 a Decree of the Federal government No. 2511-r on the state targeted programme "The Development of Health Care" was adopted (RF, the Government, Postanovlenie of 24 December 2012 No. 2511-r "Ob utverzhdenii gosudarstvennoi programmy Rossiskoi Federatsii "Razvitie zdravoohraneniya"," in: SZ RF, 31.12.2012, No. 53 (part 2) item 8019). This programme employed the "soft power" approach for the purposes of strengthening Russia's co-operation with foreign state in the sphere of health care (Subsection 8). In particular, this document set up the goal to popularize knowledge of the Russian health care system abroad in order to gain a positive image of Russia as an equal participant of international relationships in this area. The vision of "soft power" as a means of implementing external politics was incorporated into the most recently revised 2013 Concept of External Policy, approved by the Putin, which proclaims that Russia should work on "constructing a positive image of itself" (par 39 "o") by, inter alia, elaborating on the mechanisms of utilizing "soft power" (par. 10). According to this Concept, "soft power" is "a complex apparatus meant for achieving external political goals with the support of the potential inherent in civil society, information and communication technologies, humanitarian methods and technologies, and other tools which have traditionally been to alternatives to classical diplomacy" (The Concept of External Policy in the Russian Federation, "Kontseptsiya vneshnej politiki Rossijskoj Federatsii", Approved by the President on 12 February, 2013, reproduced in the Russian law database "Garant", available at: www.garant.ru, par. 20).

Notwithstanding the outlined statements and provisions it is apparent that in order to be positively perceived by the individuals of foreign states, Russia has to implement important domestic changes related to public participation in managing state affairs. For example, several legislative novelties aiming at restricting foreign influence on Russia's domestic affairs may contradict Russia's statements regarding the enhancement of alternative diplomacy in its foreign relations. In particular, the 2012 amendments to the federal law "On public associations" and the federal law "On noncommercial organizations" were introduced in Russia in 2012 obliged NGOs receiving foreign aid to register as foreign agents (Federal'nyi zakon "O vnesenii izmenenii v otdel'nye zakonodatel'nye akty Rossiiskoi Federatsii v chasti uregulirovaniia deiatel'nosti nekommercheskikh organizatsii, vypolniaiushchikh funktsii inostrannogo agenta" (20 July 2012) No.121-FZ, SZ RF (2012) No.30 item 4172). In 2014 another set of legislative amendments to the 1991 law "On the mass media" followed which restricted the amount of foreign participation in the Russian mass media to $20 \%$ (Federal'nyi zakon "O vnesenii izmenenii v Zakon Rossiiskoi Federatsii 'O sredstvakh massovoi informatsii"'(14 October 2014) No.305-FZ, Rossiiskaia Gazeta (17 October 2014)). These amendments enter into force in January 2016. Currently, the foreign co-ownership of a mass medium shall not exceed 50\%, in accordance with Art.19.1 of the RF Federal Law "On the Mass Media" as amended on 4 August 2001. The latest restriction affected, in particular, Sanoma Independent Media Group, own by the Finnish Sanom Corporation and its foreign partners.

Nonetheless, the significance of peaceful means for promoting foreign policy has been discussed in Russia already during the Soviet regime. For instance, although Gorbachev in his theory of "new thinking" promulgated the ideas of competition between capitalist and socialist states, such competition was supposed to assume peaceful forms. Gorbachev's theory prioritized human rights, making them the core of public policy, which should shape external policy of the USSR. The leading USSR political document, i.e. the Communist Party Programme, adopted in 1986, was amended, according to Gorbachev's "new thinking". Such phrases as. e.g. the idea that the people should not tolerate the existing order but instead "burry Imperialism" were removed from that programme. Nevertheless, the ideas of "peaceful 
competition" can still be found in modern Russian foreign policy. The latest statement by Russian officials on peaceful competition was made by Defence Minister Shojgu, given during his May 2013 press-conference in Helsinki. Mr. Shojgu announced that such events as e.g. NATO expansion might be seen as a stimulus to a new round in the arms race (Shojgu, S. (2013). Strategicheskie yadernye sily ostanutsya osnovnoj sderzhivayushchej siloj v regione, available at: http://www.itar-tass.com/c11/753318.html). Hence, the studies of Russian political discourses on the "soft power" are relevant.

According to the observation of $\mathrm{J}$. Nye, the success of "soft power" policies is predetermined by the reception of the foreign audience (Watanabe, Y., McConnell, D. \& Nye, J.S., 2008, viii). Insofar as there is a high degree of uncertainty whether the Nordic audience is open and ready to receive Russia's "soft power" messages, we talk not about Russia's "soft power" towards the Nordic states, the "soft power" approach towards these states. Apart of negative image of Russian political and legal realities still surfacing in Russian and foreign scholarship, the significant legal problem of implementing Russia's "soft-power" approach towards the Nordic states, is in the ambiguity of this approach per se. It is difficult to implement "soft power" due to a lack of enforcements mechanisms. Our brief sketch of the role played by the "soft power" approach in Russian legal system has shown that the issues of "soft power" are regulated by political documents, such as e.g. the Concept of Administrative Reform or the Sea Doctrine of the Russian Federation, etc. These political documents lack binding legal force. Nonetheless, they indicate the main goals of state policy, being an additional mechanism of implementing legal statutes. For instance, according to the approach of Russian researcher $\mathrm{M}$. Kondrat'eva who studies the interrelationships between political and legal documents, the meaning of political documents is in elaborating the actual provisions of statutes while not contradicting the provisions, established by the Constitution and statutory law (Kondrat'eva, M., 2010). From the perspective of individual rights, one of the most significant questions of implementing public participation in the "soft power" approach is how to vindicate the rights to such participation, if the modes in which these rights can be implemented are not guaranteed by the statutes? Hence, Russia's "soft power" approach should be applied on the basis those legal provisions which empower citizens and their associations to participate in implementing foreign policy. Let us move to the next section, examining the Russian legislation referring to public participation in implementing foreign policy.

\section{Public Participation in Implementing Foreign Policy: The Russian Statutory Law}

Although art. 80 of the 1993 Russian Constitution establishes that the President defines the direction of foreign policy, the development of this policy entails several other main actors. The Parliament ensures the legal foundation for foreign policy, and the Government is responsible for its implementation. The Security Council determines the principal directions of foreign policy, and the Foreign Ministry works out the common strategy of foreign policy. The Federal Agency on the Affairs of the CIS, and Russian Nationals Abroad, International and Humanitarian Co-operation participates in developing the strategy of foreign policy. According to the 2013 Concept of External Policy, federal authorities interact on a regular basis with NGOs, academic communities, cultural institutions, business communities, and the mass media when making decisions on international relationships (par. 102). Moreover, according to the Presidential Decree On Implementing the Foreign Policy Course of the Russian Federation, public authorities should more actively utilize the potential of civil society as well as enhance co-operation with the Public Chamber of the Russian Federation and Russian NGOs in order to increase the efficacy of external policy (RF, the President, Ukaz of 7 May 2012 No. 605 "O merakh po realizatsii vneshnepoliticheskogo kursa Rossiiskoi Federatsii," in: Sobranie Zakonodatel'stva RF, 7 May 2012, No. 19 item 2342, par. par. "f" and "u"). The provisions of many decrees of executive authorities, presiding over issues of external policy, regarding certain advisory bodies under their auspices stipulate that these advisory bodies interact with civil society when carrying out its functions (RF, the President, Ukaz of 25 December 2008 No. 1848 "On the Presidential Board on Interregional and Cultural Connections with the Foreign States", in: SZ RF, 29 December 2008, No. 52 (part 1) item 6367). Similar messages regarding co-operation with the civil society in applying the "soft power" approach towards the Nordic states can be found in the following documents, although they do not use the term "soft power": the 2001 Sea Doctrine of the Russian Federation for the Period until 2020 (RF, The Sea Doctrine of the Russian Federation for the period up to 2020, Approved by the President on 27 July 2001, reproduced in the Russian law database "Consultant," available at: www.consultant.ru); the 2009 Strategy of National Security of the Russian Federation (RF, The Concept of National Security of the Russian Federation up to 2020, Approved by the Decree of the President of 12 May 2009 No. 537, in: Sobranie Zakonodatel'stva RF, 18.05.2009, No. 20, item 2444); the 2009 Decree of the Government "On the Energy Strategy of the Russian Federation for the period up to 2030"( RF, the Government, Rasporyazhenie of 13 November 2009 No. 1715-r "Ob Energeticheskoi strategii Rossii na period do 2030 goda," in: Sobranie Zakonodatel'stva RF, 30.11.2009, No. 48, item 5836), or the 2010 Main Directions of Russian Policy in the Sphere of International Cultural 
and Humanitarian Co-Operation, Approved by the Government of the Russian Federation ("Osnovnye napravleniya politiki Rossiiskoi Federatsii v sfere mezhdunarodnogo kul'turno-gumanitarnogo sotrudnichestva", Approved by the Government of the Russian Federation on 18.12.2010. Reproduced in the Russian law database "Consultant," available at: www.consultant.ru).

Nonetheless, few of the Russian federal statutes contain the explicit references to public participation in the conduct of foreign policy, yet not to the right to participate in implementing foreign policy. The following are among them:

- $\quad$ the 2004 federal statute "On Gatherings, Meetings, Demonstrations, Marches, and Pickets", stipulating that the goals of public expression of opinion is inter alia putting forward the claims on various internal issues of political, economic, social and cultural matters, as well as on the issues of external policy (RF, Federal'nyj zakon of 19 June 2004 No. 54-FZ "O sobraniyakh, mitingakh, demonstratsiyakh, shestviyakh i piketirovanii", in: Sobranie Zakonodatel'stva RF, 21 June 2004, No. 25 item 2485, ar.t 2, par .1);

- the 2001 federal statute "On the Basic Principles of Organization of Local Self-Government in the Russian Federation", stipulating that co-operation with foreign NGOs and firms is one of the activities of the municipalities (RF, Federal'nyj zakon of 6 October 2003 No. 131-FZ "Ob obshchikh printsipakh organizatsii mestnogo samoupravleniya v Rossijskoj Federatsii," in: Sobranie zakonodatel'stva RF, 06.10.2003, №. 40 item 3822, art. 8.); and

- the 1996 federal statute "On Science and State Scientific and Technical Policy", stipulating that scientific organisations can implement scientific co-operation with the foreign legal personalities (RF, Federal'nyj zakon of 23 August 1996 No. 127-FZ "O nauke i gosudarstvennoi nauchno-tehnicheskoi politike", in: Sobranie Zakonodatel'stva RF, 26.08.1996, No. 35, item 4137).

In a way, it is no wonder that there are so few statutes referring to public participation in implementing foreign policy in Russia. Amidst the prevailing understanding of global politics steered by governments of states, there is no consensus regarding the existence of an individual right to participate in implementing foreign policy. Nonetheless, such recognized scholars as, e.g. T. Franck support the possibility of introduction into international governance "an element of participation by representatives not of governments but of perssons" (Franck, T.M., 1999, 30). Speaking the words of D. Kennedy, Franck "developed a voice" for popular participation in foreign policy-making (Kennedy, D., 2003, 425). Accordingly, there are other academicians who are of the opinion that international system could broaden of participatory opportunities of individuals, sub-groups, or sub-state entities (Held, D., 1995, Petersmann, E.-U., 1998, 26; Robertson, C.B., 2012, 439; Schaefer, M., 2011, 263). Nevertheless, nowadays it is conventional to consider that individuals participate in implementing foreign policy indirectly, i.e. via their representatives (Franck, T.M., 1999, 36).

Such conventional practices, of course, do not exclude the possibility of practicing additional avenues for individual participation in implementing foreign policy by virtue of, e.g. various activists' organizations such as the Red Cross, Amnesty International, and the Helsinki Human Rights Watch Group, transnational corporations, professional, charitable, or service organizations (Franck, T.M., 1999, 36). Moreover, the most explicit examples of practices from several regional international councils, such as the Arctic Council or the Barents Euro-Arctic Council provide for e.g. the indigenous peoples the right of permanent representation to these organs.

Legal grounds for NGOs mediating Russia's "soft power" approach towards the Nordic states are provided by the acts of public authorities. For instance, in 2012 the RF Government adopted a decree on the development of health care where the RF Ministry of Health had been encouraged to co-operate with various international organizations and NGOs for the purposes of promoting Russia's "soft power" approach (Such as the WHO, the UNICEF, the UNAIDS, or the Red Cross. RF, the Government, Postanovlenie of 24 December 2012 No. 2511-r "Ob utverzhdenii gosudarstvennoi programmy Rossiskoi Federatsii "Razvitie zdravoohraneniya"," in: SZ RF, 31.12.2012, No. 53 (part 2) item 8019, subsection 8).

Concrete mechanisms of NGOs participation in implementing the "soft power" approach are stipulated by the following decrees of the President of the Russian Federation, issued by Dmitry Medvedev. By the Presidential Decree No. 60-rp of 2 February 2010 (RF, the President, Rasporyazhenie of 2 February 2010 No. 60-rp "O sozdanii Fonda podderzhki publichnoi diplomatii imeni A.M. Gorchakova," (with subsequent amendments, the most recent amendment of 19 October 2011), in: SZ RF, 08.02.2010, No. 6 item 643), the Foundation for the Support of Public Diplomacy, named after A.M. Gorchakov was established (His Highness Aleksander Gorchakov is a prominent XIX century Russian diplomat, a Chancellor of the Russian Empire and a close friend of perhaps the most famous Russian poet A.S. Pushkin. Gorchakov has been recognized for his outstanding diplomatic skills. See, for example, Semanov, S.N. (1963). A.N. Gorchakov - russkii diplomat XIX veka (in Russian). Moscow: Izdatel'stvo sotsial'no-ekonomicheskoi literatury). This Foundation is in charge of providing support to the Russian NGOs willing to promote the "soft power" approach and public diplomacy. Projects, related to implementing the "soft power" approach towards the EU state and the states of the Arctic 
region, are among the thematic priority areas, sponsored by this foundation in 2014 (See, the list of thematic priority areas of the Foundation (in Russian), reproduced on its official web-page, available at: http://gorchakovfund.ru/upload/ iblock/ba7/ba7f2f8161d4e57d2d690eb161f6a519.pdf, last retrieved 3 October 2013). On the same date with the establishment of the Gorchakov Foundation, the non-commercial partnership "Russian International Affairs Council" was set up by the Presidential Decree No. 58-rp (RF, the President, Rasporyazhenie of 2 February 2010 No. 59-rp "O sozdanii nekommercheskogo pratnerstva "Rossiiskii sovet po mezhdunarodnym delam"' (with subsequent amendments, the most recent amendment of 22 February 2012), in: SZ RF, 08.02.2010, No. 6 item 642). This non-profit organization, based on the requirement of membership, is aimed at strengthening peace, friendship and solidarity between the peoples, preventing international conflicts and promoting crises settlement (See the official web-page of the "Russian International Affairs Council", available at: http://russiancouncil.ru/en/about-us/what_is_riac, last retrieved 3 October 2013). In his 2012 Decree On Implementing the Foreign Policy Course of the Russian Federation President Putin calls upon the public authorities to utilize the potential of the Gorchakov Foundation in implementing Russia's foreign policy by enhancing its participation in international expert and discussion forums and in humanitarian co-operation. Notably, the ideas regarding the establishment of both, the Gorchakov Foundation and the "Russian International Affairs Council", came from the NGOs which are the co-founders of these entities.

Another semi-formal avenue for public participation in implementing Russia's "soft power" approach is the Valdai International Discussion Club. This Club which is an All-Russia forum for leading Russian and international experts in history, politics, economics and international relations. Its main goal is to maintain a global dialogue about Russia and to provide an "independent, and unbiased scholarly analysis of political, economic and social processes in Russia and the world" (See the web-page of the Valdai Club at: http://valdaiclub.com, last retrieved 2 October 2013). Public authorities take active part in its activities. To start with, the Valdai Club was established in 2004 by one of the leading Russian news and information agency RIA Novosti and the Council on Foreign and Defense Policy. Moreover, the Russian regions who host the next summit of the Valdai Club take active part in organizing practical and other arrangements, related to this forthcoming event by virtue of allocating the necessary resources (See for example, the 2008 Decree of the Administration of Rostov Oblast on hosting the summit of the Valdai Club. RF, Rostov Oblast, the Administration, Rasporyazhenie of 5 September 2008 No. 269 "O prieme v Rostovskoi oblasti uchastnikov pyatogo zasedaniya Mezhdunarodnogo diskussionnogo kluba "Valdai", reproduced in the Russian law database "Garant," available at: http://base.garant.ru). Its potential to apply the "soft power" approach is supported by the fact that it provides for invited foreign experts and opportunity of annual face-to-face meetings with the President as well as with the representatives of NGOs and universities. Although the summits of the Valdai Club are held behind closed doors, the news about its contents is regularly broadcasted by the Russian and the foreign media corporations (See, for example, the information about the most recent summit of the Valdai Club at the BBC news-media corporation: Kendall, B. Russia's Putin shines at Valdai summit as he castigates West, available at: http://www.bbc.co.uk/news/world-europe-24170137; Kendall, B. Russian PM Putin defends bid for presidency, available at: http://www.bbc.co.uk/news/world-europe-15703811). The annual summits of this Club are another proof testifying to the ability of the state to act in conjunction with the civil society in spreading a positive image of Russia via the mass media. The mechanisms of state-civil society co-operation are illustrated also with the activities of the all-Russia forum "State and Civil Society: Co-operation in the Name of Development" run under the aegis of the Public Chamber of the Russian Federation which is a consultative organ comprised of NGO representatives (Information about this forum is available at the official web-page of the Public Chamber: http://www.oprf.ru/press/news/2015/newsitem/27711).

At the same time, Russian legal system is rather restrictive when it comes to the opportunities for Nordic NGOs, universities, and firms to implement their "soft power" approach in Russia. As Russia attempts to disseminate cultural as well as other values in the Nordic states, the Nordic NGOs should also be provided with similar legal opportunities. Nonetheless, in its attempts to promote its own cultural values abroad, Russia is at the same time concerned with foreign influence on its own internal affairs. The provision on the rejection of any attempt to intervene in its internal affairs by "the destructive and illegitimate" usage of "soft power" by foreign states is incorporated into the 2013 Concept of External Policy (par. 20). Hence, the issue of reciprocity in implementing a soft power approach to co-operation with Nordic states is also significant in the light of legal developments in Russia.

\section{Ad-hoc Mechanisms of Soft-Power Approach}

1. Incorporating the issues of bi-lateral co-operation into the agenda of Nordic-Russian official meetings is perhaps among the most obvious mode of implementing the "soft power" approach. There are examples when the state and civil society join efforts in order to implement "soft power" policies, for instance, after the most recent official visit of President 
Putin to Finland in June 2013. President Putin discussed with President Niinistö inter alia the prospects of co-operation in the sphere of research and education. As a result of this visit, the representatives of Åbo Akademi University, Turku University, the Turku Science Park and the Skolkov Foundation, signed an agreement on co-operation in life science and ICT industries (Turku Science Park Oy ja turkulaiset tiedeyhteisöt käynnistävät yhteistyön Skolkovon teknologiakeskittymän kanssa (in Finnish), available at: http://www.turkusciencepark.com/fi/spark-uutiset/1060/turkuscience-park-oy-ja-turkulaiset-tiedeyhteisot-kaynnistavat-yhteistyon-skolkovon-teknologiakeskittyman-kanssa/). However, there are no clear-cut procedural legal rules which would stipulate the procedure of public participation in formulation of the agenda of official meetings. Nonetheless, the examples of legal mechanisms allowing citizens to implement indirect participation in the formulation of such agenda can be found. For instance, NGOs and universities can act via their representatives in the Human Rights Council in their pursuits to recommend certain human rights oriented agenda for official meetings. The President's Human Rights Council is the advisory organ to the President, consisting of representatives from public authorities, NGOs, universities, mass media, and cultural institutions (RF, the President, Ukaz of 1 February 2011 No. 120 "O sovete pri Prezidente Rossijskoj Federatsii po razvitiyu grazhdanskogo obshchestva $i$ pravam cheloveka", SZ RF, 7 February 2011, No. 6 item 852 (with subsequent amendments, the most recent amendment of 1 April 2013). This organ keeps the President updated with kept the President updated about the human rights' situation in Russia and abroad. It also acts as a mediator with the institutions of civil society, developing strategies of public participation in modern civil society and introducing proposals to the President.

2. Student and teacher exchange and mobility; implementing joint projects. Teacher and student exchange and mobility contribute in applying Russia's "soft power" approach towards the Nordic states. Most probably independent of discourses about "soft power" approach, but still the Russian Government adopted the Decree No. 220 of 9 April 2010, which had introduced new governmental monetary grants for attracting leading scientists, including those who reside abroad, to Russian Educational Institutions (RF, the Government, Postanovlenie of 9 April 2010 No 220 "O merakh po privlecheniyu vedushchikh uchyonykh $v$ rissiiskie obrazovatel'nye uchrezhdeniya vysshego professional'nogo obrazovaniya, nauchnye uchrezhdeniya gosudarstvennykh akademii nauk i gosudarstvennye nauchnye tsentry Rossiiskoi Federatsii," in: SZ RF, 19.04.2010, No. 16 item 1907 (with subsequent amendments, the most recent amendment of 30 May 2012). These grants are aimed inter alia at building sustainable links between Russian institutions of higher learning and the world's leading universities and science schools (See the official web-page regarding implementation of the Decree No. 220, available at: http://www.p220.ru/en/). It is a significant step from Russian public authorities, indicating that Russia is increasingly expanding the policy of co-operation between the Russian and the foreign universities. There is a strong potential in mobilizing the universities to promote the "soft power" approach as e.g.by 2009, the number of institutions of higher education in Russia numbered 1134 across the country, according to the 2010 UNESCO Science Report (UNESCO Science Report, 2010, The Current Status of Science around the World (Paris, France: UNESCO, 2010). Such initiatives not only contribute in applying Russia's "soft power" abroad. They also provide for the Nordic universities opportunities to spread their "soft power" in Russia. As the result of such scientific cooperation Nordic academicians would be in a position to convey their research philosophy to Russian colleagues and hence to implement Nordic soft power policies in Russia.

\section{Conclusions}

It is difficult to deal with citizens' participation in implementing the "soft power" approach from the point of view of rights. As mentioned previously, legal instruments do not operate with the term "soft power". However, various participatory modes are suggested by disparate provisions of Russian political documents, the decrees of the public authorities, as well as by Nordic-Russia international agreements on co-operation.

Some of these mechanisms remain latent for civil society in their capacity to act as avenues for exerting the "soft power". On the other hand, such initiatives as, for example, the "Russian International Affairs Council," the Gorchakov Foundation, or the Valdai Club, are examples of Russian NGOs whose main purpose is to engage in a dialogue with the foreign NGOs, promoting Russia's "soft power" approach. In all the cases discussed earlier there is always a danger that public participation turns into mere co-optation when the state "orders" the agenda with the aim of adjusting the outcomes. Nonetheless, such risks are unavoidable, taking into consideration the nature of the "soft power" approach, when the public authorities are supposed to act in conjunction with the civil society in pursuits to draw a positive image of Russia towards the foreign states. Overall it is accurate to characterize public participation in implementing Russia's "soft power" approach as a "top-down" mode of participation. 


\section{Acknowledgement}

This research is partly financed by the Russian Foundation for the Humanities (RGNF), grant No. 15-03-00626, Access of Individuals and Legal Entities to Implementing Russia's Foreign Policy towards the Nordic States.

\section{References}

Ausland, J.C. (1986). Nordic Security and the Great Powers. Boulder and London: Westview Press.

Barber, B.R. (1990). Strong Democracy: Participatory Politics for a New Age. Berkeley: University of California Press, 197.

Congyan, C. (2013) New great powers and international law in the 21st century. 24 (3) European Journal of International Law.

Franck, T.M. (1999). The Empowered Self. Law and Society in the Age of Individualism. New York: Oxford University Press Inc.

Engle, E. (2011). From Russia with Love: the EU, Russia, and Special Relationships. 10 Richmond Journal of Global Law and Business.

Grant, T. (2009). A League of their own: the Rationale for an International Alliance of Democracies. George Washington International Law Review.

Held, D. (1995). Democracy and the Global Order: from the Modern State to Cosmopolitan Governance. Stanford: Stanford University Press.

Hill, F. (2006). Moscow discovers Soft Policy. Current History.

Hobér, K. (2009). Law and Policy in the Russian Oil and Gas Sector. 27(3) Journal of Energy \& Natural Resources Law .

Kennedy, D. (2003). Tom Franck and the Manhattan School. New York University Journal of International Law \& Politics.

Kinnunen, T. \& Kivimäki, V. (2011). History of Warfare. Volume 69: Finland in World War II: History, Memory, Interpretations. Leiden: Brill.

Kondrat'eva, M. (2010). Pravovoe i politicheskoe regulirovanie $v$ konstitutsionnom prave: nekotorye problemy sootnosheniya (in Russian). 5 Konstitutsionnoe i munitsipal'noe pravo.

Legvold, R. (ed.) (2007). Russian Foreign Policy in the Twenty-First Century and the Shadow of the Past. New York, NY, USA: Columbia University Press.

Lucas, E. (2008). The New Cold War: Putin's Russia and the Threat to the West. USA: Palgrave Macmillan.

Noelle Casper, K. (2009). Oil and Gas Development in the Arctic: Softening of Ice Demands Hardening of International Law. Natural Resources Journal

Nye, J. \& Donahue, J. (2000). Governance in a Globalizing World. Washington, USA: Brookings Institution Press.

Watanabe, Y., McConnell, D. \& Nye, J.S. (eds.) (2008). Soft Power Superpowers: Cultural and National Assets of Japan and the United States. USA: M.E. Sharpe, Inc.

Nye, J.S. (2004). Soft Power: The Means to Success in World Politics. New York: Public Affairs.

Putin, v. (2012). Rossiya i menyayushchijsya mir. Moskovskie novosti, 27 February 2012.

Petersmann, E.-U. (1998). How to Constitutionalize International Law and Foreign Policy for the Benefit of Civil Society?. Michigan Journal of International Law.

Robertson, C.B. (2012). The Politization of Judgment Enforcement. Case Western Reserve Journal of International Law.

Sakwa, R. (2012). The Problem of 'the International' in Russian Identity Formation. 49 International Politics.

Schaefer, M. (2011). Constraints on State-Level Foreign Policy: (Re) Justifying, Refining and Distinguishing the Dormant Foreign Affairs Doctrine. Seton Hall Law Review.

Semanov, S.N. (1963). A.N. Gorchakov - russkii diplomat XIX veka (in Russian). Moscow: Izdatel'stvo sotsial'no-ekonomicheskoi literatury.

Shojgu, S. (2013). Strategicheskie yadernye sily ostanutsya osnovnoj sderzhivayushchej siloj v regione, available at: http://www.itartass.com/c11/753318.html.

Svendsen, K. (2008). The Russian Regime for Subsoil Use, Energy and Environmental Policy in the High North. 10(4) Environmental Law Review.

Ticktin, H. (2008). The Inherent Instability of the Ruling Elite. White, S. (ed.) Politics and the Ruling Group in Putin's Russia, 63-86. USA: Palgrave Macmillan.

Tsygankov, A. (2006). If not by Tanks, then by Banks? The Role of Soft Power in Putin's Foreign Policy. 58 (7) Europe-Asia Studies.

Wolff, L. (1994). Inventing Eastern Europe: the Map of Civilization on the Mind of the Enlightenment. Stanford: Stanford University Press. 